\title{
Fabrikasi dan Surface Finishing Minitube dengan Mesin Bubut untuk Bahan Baku Ring Jantung
}

\author{
E. Pujiyulianto ${ }^{*}$, Suyitno ${ }^{1}$ \\ 1.Departemen Teknik Mesin dan Industri, Fakultas Teknik, Universitas Gadjah Mada. \\ JI. Grafika No. 2, Kompleks UGM, Yogyakarta 55281, Indonesia. \\ e-mail: *1 ekopuji39@gmail.com
}

\begin{abstract}
Abstrak
Penelitian ini bertujuan untuk mengetahui unjuk kerja proses pembuatan minitube dan proses surface finishing dengan menggunakan mesin bubut sebagai bahan baku ring jantung. Urutan proses pembuatan minitube adalah proses boring dan face turning, Proses boring dan face turning harus dilakukan secara berurutan, setelah proses boring dan face turning dilakukan proses pengamplasan dan mechanical polishing sebagai proses surface finishing. Hasil percobaan unjuk kerja berhasil mendapatkan minitube dengan ukuran diameter dalam $3 \mathrm{~mm}$, diameter luar 3,5 $\mathrm{mm}( \pm 0,1)$ dan panjang $30 \mathrm{~mm}$., harga kekasaran permukaan $(\mathrm{Ra})$ hasil proses surface finishing adalah 0,04 $\mu \mathrm{m}$ untuk AISI $316 \mathrm{~L}$ dan 0,1 $\mu \mathrm{m}$ untuk CP-Titanium grade 2. Harga kekasaran (Ra) permukaan yang dihasilkan dari proses surface finishing masuk kedalam standar harga kekasaran permukaan ( $\mathrm{Ra}$ ) maximum ring jantung yaitu $0,6 \mu \mathrm{m}$. Hasil penelitian menunjukan bahwa proses pembuatan minitube untuk bahan baku ring jantung dapat dilakukan dengan menggunakan mesin bubut, dan Proses surface finishing dapat digunakan sebagai prelimanary proses untuk menghaluskan permukaan minitube sebelum dilakukan proses fabrikasi ring jantung.
\end{abstract}

Kata kunci: Ringjantung, AISI 316 L, CP-Titanium grade 2, Mesin Bubut.

\begin{abstract}
This study aims to determine the performance of the minitube making process and surface finishing processes using a lathe as a raw material for stent. The order of the minitube making process is the boring face turning process, and then sanding and mechanical polishing processes as a surface finishing process. The results of the experiment succeed in obtaining a minitube with a diameter size of $3 \mathrm{~mm}$, an outer diameter of $3.5 \mathrm{~mm}$ ( \pm 0.1 ) and a length of $30 \mathrm{~mm}$. The surface roughness $(\mathrm{Ra})$ of the surface finishing process is 0.04 um for AISI $316 \mathrm{~L}$ and 0.1 um for CP-Titanium grade 2. Roughness (Ra) surfaces produced from surface finishing processes are entered into the standard of maximum surface roughness $(\mathrm{R} a)$ stent which is $0.6 \mu \mathrm{m}$. The results shows that the minitube making process for stent raw material can be done using a lathe, and the surface finishing process can be used as a prelimanary process to smooth the surface of the minitube before the stent fabrication process is carried out.
\end{abstract}

Keywords: Stent, AISI 316 L, CP-Titanium grade 2, Lathe Machine.

\section{PENDAHULUAN}

Ring (stent) merupakan tube kecil yang dipasang pada arteri koroner untuk membuka penyempitan arteri koroner (Hermawan \& Mantovani, 2013). Prosedur pemasangan ring dilakukan dengan menggunakan kateter balon. Ring disusutkan lalu dipasang pada kateter 
balon kemudian dikirim ke arteri koroner yang menyempit, setelah sampai pada arteri koroner yang menyempit, ring di ekspansi dengan mengembangkan balon pada kateter. Ring didesain untuk terdeformasi pada daerah plastis sehingga akan terus mengembang setelah mengalami ekpansi meskipun balon telah dikempiskan (Suryawan, 2017).

Material logam yang sering digunakan sebagai biomaterial untuk ring jantung adalah titanium, cobalt, dan Stainless steel (316L) (Saraf \& Yadav, 2018) dan (Ratner, 2004). Pertimbangan pemilihan material sebagai material implant adalah ketahanan korosi, biokompatibilitas, dan beberapa sifat mekanik yang dimiliki oleh material seperti kekerasan, keuletan, dan kekuatan ( $\mathrm{Li}, \mathrm{dkk}, 2017)$, dan keseimbangan antara kekuatan dan flexibelitas (Catalano, dkk, 2017). Ring yang secara fungsi diperuntukan untuk kebutuhan medis, maka harus ada pengembangan teknologi fabrikasi untuk menghasilkan sifat fisik, kimia dan sifat mekanik yang sesuai (Fang, dkk, 2013). Tiga faktor utama yang harus dipertimbangkan dalam mendesain ring adalah aspek medical, engineering, dan manufacturing (Tontowi, dkk, 2014) dan aspek yang dapat diamati pada ring adalah jenis material, bentuk, proses fabrikasi, dan geometri (Stoeckel, dkk 2002).

Teknologi proses fabrikasi utama pada proses pembuatan ring jantung adalah proses pembuatan ring dan proses pembuatan minitube. Pada umumnya proses pembuatan ring dilakukan dengan mesin laser cutting (Demir, dkk, 2013). Penelitian terkait proses pembuatan ring sudah banyak dilakukan, dan sudah sampai kepada proses produksi dan manufaktur, namun, penelitian terkait proses pembuatan minitube masih jarang dilakukan. Beberapa penelitian proses pembuatan minitube pernah dilakukan oleh Fang, dkk (2012) dengan menggunakan metode multipass cold drawing dengan material magnesium alloy ZM21. Tujuan penelitian yang dilakukan oleh Fang, dkk (2013) adalah untuk menghasilkan bentuk mintube yang presisi dengan bentuk struktur mikro yang halus. Penelitian yang dilakukan oleh Fang, dkk (2013) berhasil mendapatkan minitube dengan ukuran diameter luar adalah 2,9 mm, dan ketebalan 0, $27 \mathrm{~mm}$ (Fang, dkk, 2013). Metode lain yang digunakan untuk membuat minitube adalah ekstruksi atau cold drawing, metode ekstruksi atau cold drawing merupakan metode yang paling banyak digunakan untuk membuat minitube (Morajev \& Mantovani, 2011). Beberapa penelitian yang pernah dilakukan terkait proses pembuatan minitube untuk ring dengan menggunakan ekstruksi adalah ekstruksi bulk material Fe-Mn sebagai biodegradable ring (Nordin, $\mathrm{dkk}, 2013)$, ekstruksi magnesium tube sebagai biodegradable stent (Ge, dkk, 2012), dan mintube extrusion atau cold drawing pada material AISI 316 L (Hassel, dkk, 2007), selain metode multipass cold drawing dan metode ektruksi ada beberapa metode untuk membuat minitube dengan menggunakan advance manufacturing processes, yaitu proses electroforming (Morajev \& Mantovani, 2011), powder metallurgy (Morajev \& Mantovani, 2011), blow molded tubing untuk ring berbahan dasar polimer (United State Paten No. US 20090146348A1, 2009), single-screw extruder yang diikuti oleh proses CNC engraving dengan bahan dasar polimer L-Lactide (LLA), Trimethylene carbonate (TMC) dan Glycolida (GA) (Dong, dkk, 2013). Metode proses pembuatan minitube dengan menggunakan multipass cold drawing, ektruksi, dan beberapa metode advance manufacturing yang telah dijelaskan di atas membutuhkan beberapa peralatan khusus dan biaya yang mahal. Penelitian ini mencoba melakukan proses pendekatan pembuatan minitube dengan menggunakan mesin bubut konvensional (conventional turning machine), dengan pertimbangan lebih murahnya biaya proses produksi, serta ketersediaan alat yang mudah didapatkan. Proses pembuatan minitube dengan menggunakan mesin bubut konvensional pernah dilakukan oleh Hendra Hermawan dan Diego Mantovani (2013). Keuntungan penggunaaan mesin bubut konvensional adalah tidak merubah sifat mekanik material yang disebabkan oleh tidak adanya 
perubahan struktrus mikro dan tidak adanya mekanisme work hardening dan grain refinement pada material.

Ring jantung harus memiliki permukaan yang halus, standar kekasaran permukaan ring adalah 0,11 $\mu \mathrm{m}-0,4 \mu \mathrm{m}$ (Gocke, dkk 2008), beberapa metode yang digunakan untuk menghaluskan permukaan ring adalah electropolishing (Sojitra, 2010). Permukaan ring yang halus akan memudahkan proses pengiriman ring ke arteri koroner, serta mengurangi resiko gesekan antara dinding arteri (endothelium) dengan ring (Raval, dkk, 2005), beberapa faktor yang dipengaruhi oleh kualitas permukaan ring adalah banyaknya jumlah protein yang melekat pada permukaan ring jantung (Raval, dkk, 2005). Beberapa literatur menyebetukan bahwa kualitas permukaan ring menentukan thrombogenity, inflammation, dan vascular wound-healing (Mazinani, 2014).

\section{METODE PENELITIAN}

Deskripsi langkah penelitian yang dilakukan adalah :

1. Pemilihan Material Ring

Material yang digunakan pada penelitian ini adalah AISI 316 L dan CP- Titanium grade 2. Pemilihan material ring didasarkan pada kebutuhan sifat yang harus dimiliki oleh ring yaitu ketahanan korosi, bikompatibelitas, kombinasi sifat mekanik yang baik seperti kekerasan, keuletan, dan kekuatan (Li, dkk, 2017), dan keseimbangan antara kekuatan dan flexibelitas (Catalano, dkk, 2017). AISI 316 L dan Cp-Titanium grade 2 memiliki ketahanan korosi yang sangat baik, hal ini disebabkan oleh terbentuknya lapisan pasif oksida pada kedua permukaan logam.

\section{Proses Boring}

Proses boring dilakukan untuk melubangi bagian tengah rod dengan diameter $3 \mathrm{~mm}$ dan kedalaman $30 \mathrm{~mm}$. Proses boring dilakukan dengan menggunakan mesin bubut konvensional jenis Do ALL'13, Harrison, UK. Kecepatan putar spindle yang digunakan adalah $800 \mathrm{rpm}$ dengan cairan pendingin menggunakan oli. Proses boring ditunjukan pada gambar 1.

3. Proses face turning

Proses face turning dilakukan untuk memakan permukaan material sampai didapatkan diameter luar sebesar 3,5 $\mathrm{mm}$.

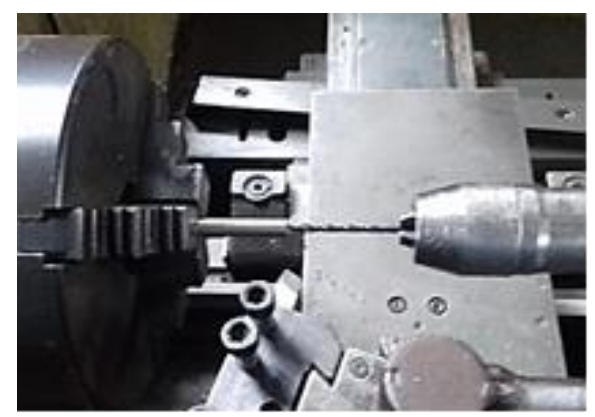

Gambar 1. Proses Boring.

Proses face turning dilakukan dengan menggunakan mesin bubut konvensional jenis Do ALL'13, Harrison, UK. Kecepatan putaran spindle yang digunakan adalah $1200 \mathrm{rpm}$ dengan cairan pendingin menggunakan oli. Proses face turning ditunjukan pada gambar 2. 


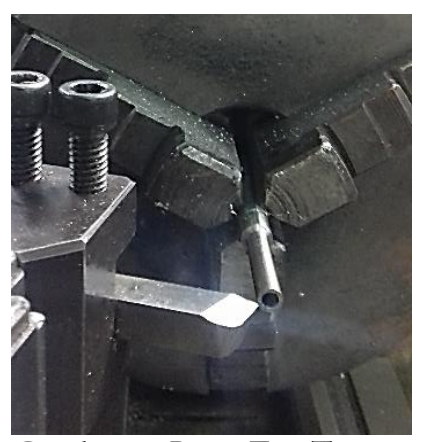

Gambar 2. Proses Face Turning.

4. Pengamplasan

Proses pengamplasan dilakukan untuk menghilangkan alur proses bubut pada permukaan minitube (Suryawan, 2017). Pengamplasan dilakukan dari amplas yang paling kasar hingga amplas paling halus, berikut urutan proses pengamplasan, dimulai dari amplas 120 mesh, 400, 800, 1000, dan 2000 mesh. Proses pengamplasan dilakukan dengan menggunakan mesin bubut konvensional jenis Do ALL'13, Harrison, UK. Kecepatan putar spindle yang digunakan adalah $370 \mathrm{rpm}$ dengan cairan pendingin menggunakan air.

\section{Mechanical Polishing}

Proses mechanical polishing merupakan proses penghalusan permukaan minitube dengan menggunakan kain bludru. Proses mechanical polishing dilakukan dengan menggunakan mesin bubut konvensional jenis Do ALL'13, Harrison, UK. Kecepatan putar spindle yang digunakan adalah $370 \mathrm{rpm}$ dengan cairan pendingin menggunakan air dan paste polishing.

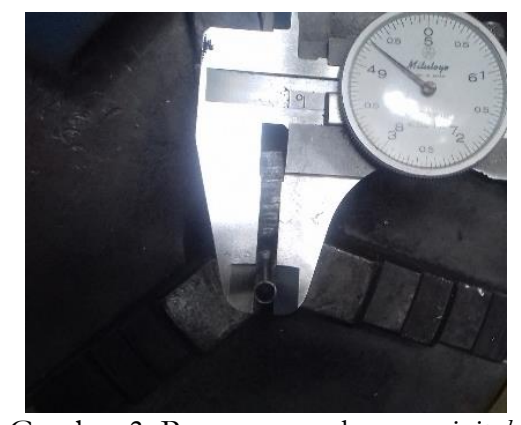

Gambar 3. Proses pengukuran minitube

\section{Pengukuran minitube}

Pengukuran minitube dilakukan untuk memastikan bahwa dimensi akhir minitube sesuai dengan dimensi yang dibutuhkan untuk ring jantung. Ukuran minitube yang dibutuhkan untuk ring adalah $3 \mathrm{~mm}$ diameter dalam, $3,5 \mathrm{~mm}( \pm 0,1)$ diameter luar, dan panjang $30 \mathrm{~mm}$. Pengukuran minitube dilakukan dengan menggunakan jangka sorong seperti yang ditunjukan pada gambar 3. 


\section{HASIL DAN PEMBAHASAN}

\subsection{Hasil Penelitian}

Proses pembuatan minitube yang dilakukan dengan menggunakan mesin bubut mengalami beberapa kegagalan. Kegagalan yang terjadi pada pembuatan minitube disebabkan oleh proses boring dan face turning yang tidak dilakukan secara berurutan, penggunaan tail stock saat proses face turning, dan penggunaan mesin yang tidak konsisten. Kegagalan yang terjadi dapat berupa patah, ketidakhomogenan ukuran diameter minitube, dan ketidakhomogenan ketebalan minitube. Kegagalan yang disebabkan oleh proses boring dan face turning yang tidak dilakukan secara berurutan dapat dilihat pada gambar 4 dibawah ini.
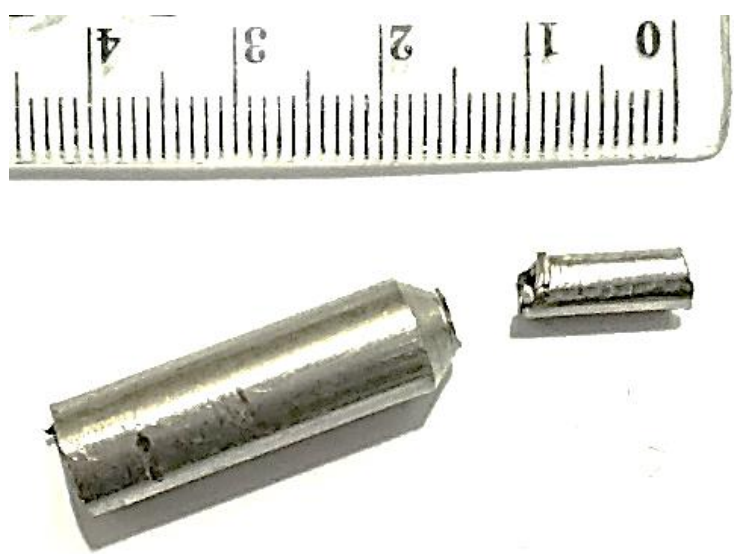

Gambar 4. Patah pada minitube disebabkan oleh proses boring dan face turning tidak dilakukan secara berurutan

Kegagalan yang disebabkan oleh penggunaan tail stock mengakibatkan ketidakhomogenan ukuran diameter minitube. Ketidakhomogenan ukuran diameter minitube dapat dilihat pada gambar 5 dibawah ini.

Ukuran diameter bagian A adalah $4 \mathrm{~mm}$ dan bagian $\mathrm{B} \quad 3,5 \mathrm{~mm}$ sehingga mengakibatkan ukuran bagian A lebih besar dibandingkan dengan bagian B. Ketidakhomogenan ukuran diameter minitube disebabkan oleh defleksi $(\delta)$ yang timbul pada ujung minitube saat proses face turning. Adanya gaya (Fy) yang timbul saat proses face turning mengakibatkan ujung minitube terdorong ke arah sumbu -y seperti yang ditunjukan pada gambar 6 .

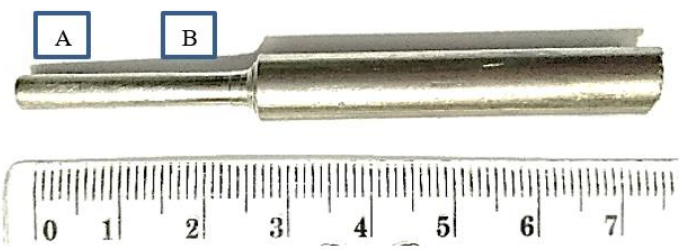

Gambar 5. Ketidakhomogenan ukuran diameter minitube, bagian A memiliki diameter yang lebih besar di bandingkan bagian $B$ 


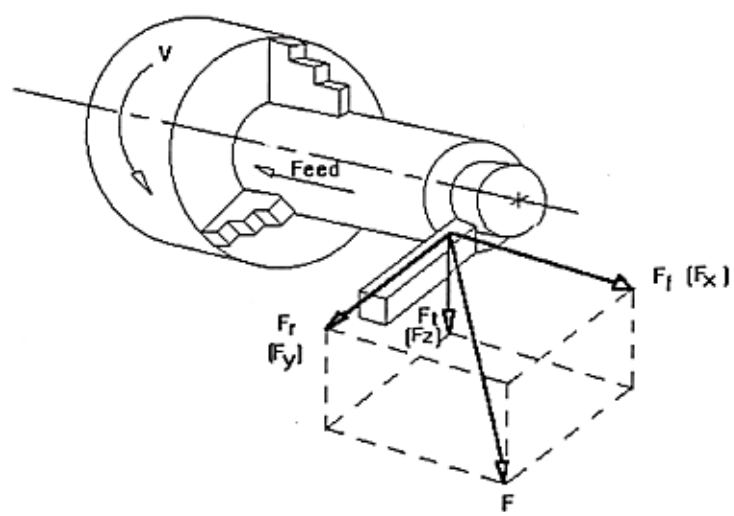

Gambar 6. Arah gaya pada mesin bubut.

Defleksi (8) pada ujung minitube dihitung dengan menggunakan dial indicator. Hasil pengukuran defleksi ditunjukan pada gambar 7. Kedalaman pemakanan sebesar 0,5 mm dengan feeding rate sebesar 0,008 - 0,1 mm / putaran menghasilkan defleksi $(\delta)$ sebesar 0,23 $\mathrm{mm}$ pada ujung minitube dengan panjang $3 \mathrm{~mm}$, seperti yang ditunjukan pada gambar 7 dibawah ini

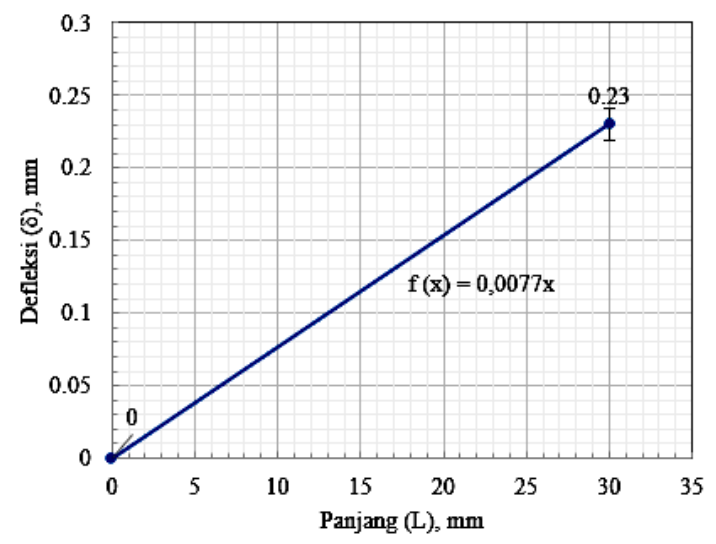

Gambar 7. Defleksi ( $\delta$ ) pada ujung minitube

Kegagalan yang disebabkan oleh penggunaan mesin yang tidak konsisten dapat dilihat pada gambar 8 (B). Penggunaan mesin yang tidak konsisten mengakibatkan ketidakhomogenan ukuran ketebalan minitube yang dapat mengakibatkan retak dan berlubang pada bagian yang tipis seperti yang ditunjukan pada gambar 8 (A). Ketidakhomogenan ketebalan minitube terjadi karena adanya simpangan pada minitube saat menggunakan mesin bubut yang berbeda, ilustrasi simpangan $(\Delta \mathrm{x})$ yang timbul pada mesin bubut ditunjukan pada gambar 9. Besarnya simpangan $(\Delta \mathrm{x}$ ) dihitung dengan jarak $25 \mathrm{~mm}$ dari kepala tetap (chuck) mesin bubut, interval pengukuran yaitu $5 \mathrm{~mm}$ dari ujung minitube hingga ke ujung kepala tetap (chuck) dengan menggunakan dial indicator.

Hasil pengukuran simpangan $(\Delta \mathrm{x})$ dengan menggunakan dial indicator menunjukan bahwa simpangan terbesar adalah $0,41 \mathrm{~mm}$ pada ujung minitube degan jarak $25 \mathrm{~mm}$ dari kepala 
tetap (chuck) mesin bubut. Besarnya simpangan untuk masing masing titik pengukuran ditampilkan pada gambar 10.

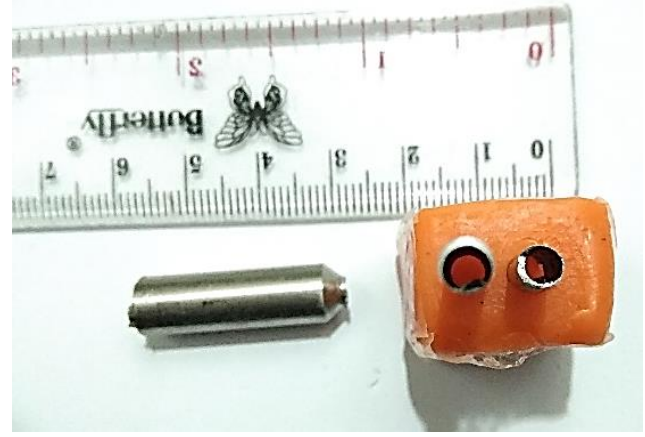

(a)

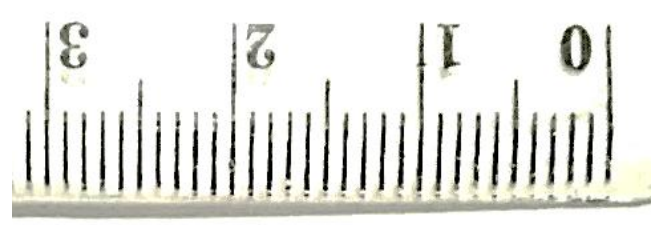

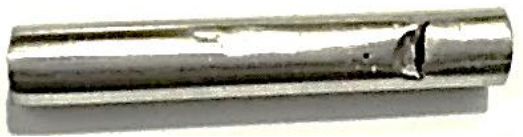

(b)

Gambar 8. Foto kegagalan minitube : (a) Ketidakhomogenan ketebalan minitube dan (b) minitube yang mengalami retak dan berlubang

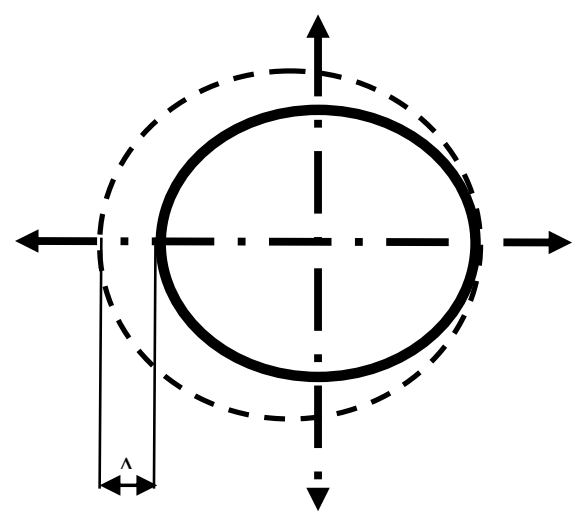

Gambar 9. Ilustrasi simpangan $(\Delta \mathrm{x})$ yang timbul pada mesin bubut

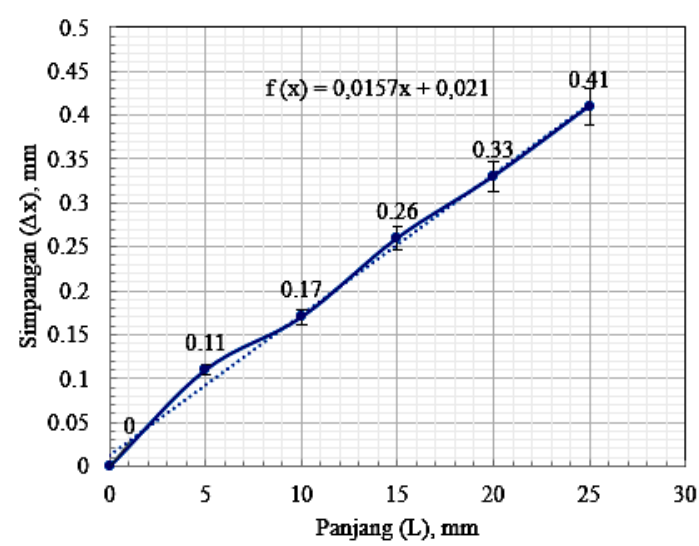

Gambar 10. Besarnya simpangan $(\Delta \mathrm{x})$ pada masing masing titik pengukuran. 
Hasil analisis gambar 4 - 10 menjadi evaluasi untuk membuat minitube, maka proses pembuatan minitube selanjutnya dilakukan dengan proses boring dan face turning yang berurutan, tanpa menggunakan tailstock dan dilakukan pada mesin yang sama tanpa ada perubahan benda kerja.

Hasil proses boring dan face turning yang dilakukan secara berurutan berhasil membuat produk minitube. Produk minitube AISI 316 L dan CP Ti grade 2 ditampilkan pada gambar 11.

Produk minitube pada gambar 11 memiliki kualitas permukaan yang baik, permukaan yang mengkilat dan nilai kekasaran permukaan yang kecil $(\mathrm{Ra})$ yaitu $0,55 \mu \mathrm{m}$ untuk material AISI $316 \mathrm{~L}$ dan $0,45 \mu \mathrm{m}$ untuk material CP-Ti-2. Harga kekasaran permukaan (Ra) minitube yang optimal dihasilkan dari proses mechanical polising dengan menggunakan abrasive paper dan kain bludru untuk menghilangkan goresan (kerf) hasil proses face turning seperti yang ditunjukan pada gambar 13.

Proses mechanical polishing dengan menggunakan abrsive paper dimulai dari abrasive paper berukuran 120 mesh hingga 1000 mesh dan dilanjutkan dengan penggunaan kain bludru yang ditambahkan sedikit auto sol untuk mengkilatkan dan menghilangkan goresan (scretch) pada permukaan minitube. Harga kekasaran permukaan hasil proses mechanical polishing ditunjukan pada gambar 12.

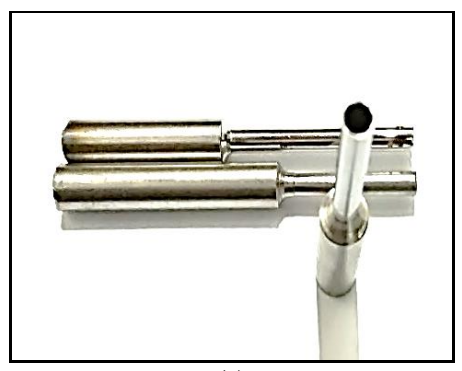

(a)

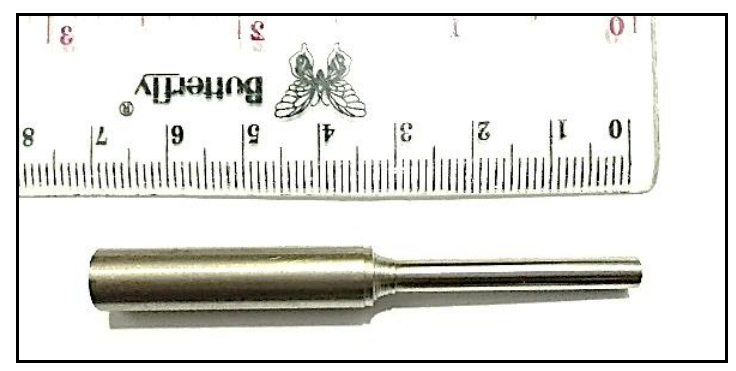

(b)

Gambar 11. Foto produk minitube ; (A) minitube AISI 316 L dan CP-Ti Grade 2. (B) Skala ukuran minitube.

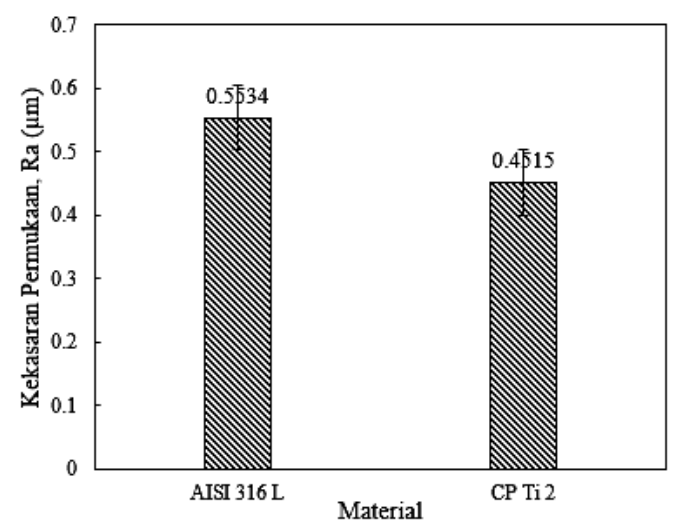

Gambar 12. Kekasaran permukaan (Ra) minitube hasil proses mechanical polishing. 


\subsection{Pembahasan}

Proses boring dan face turning harus dilakukan secara berurutan, apabila proses tidak dilakukan secara berurutan akan menyebabkan kegagalan minitube seperti yang ditunjukan pada gambar 4. kegagalan terjadi akibat adanya getaran pada mesin bubut konvensional saat proses boring. Minitube hasil proses face turning memiliki ketebalan yang kecil sehingga tidak mampu menahan getaran yang mengakibatkan keretakan dan akhirnya patah.

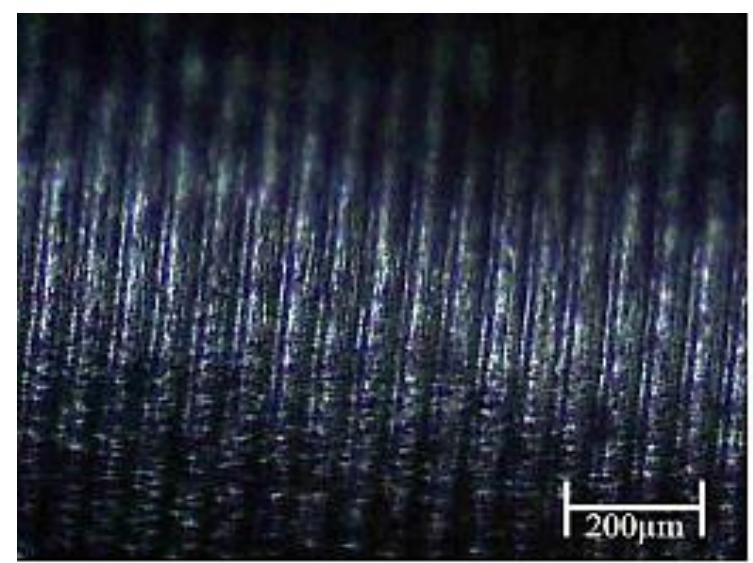

Gambar 13. Foto Mikro Goresan (Kerf) Hasil Proses Face Turning (Suryawan, 2017)

Kegagalan tetap terjadi pada saat proses boring dan face turning dilakukan. Kegagalan yang terjadi pada minitube ditampilkan pada gambar 5 dan gambar 8. Gambar 5 menampilkan bentuk ukuran diameter minitube yang tidak homogen. Bagian A memiliki diameter yang lebih besar dibandingkan dengan bagian B, diameter bagian A adalah $4 \mathrm{~mm}$ dan bagian B adalah 3,5 $\mathrm{mm}$. Ketidakhomogenan ukuran diameter minitube disebabkan oleh gaya $(\mathrm{F})$ pada arah sumbu y negatif yang dihasilkan pada saat proses face turning. Gaya (-Fy) tersebut menimbulkan

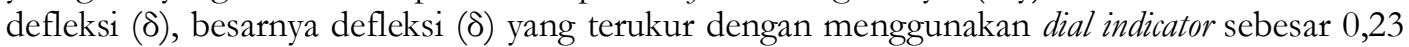
mm. Pada saat posisi pahat berada ditengah minitube maka defleksi $(\delta)$ pada minitube mengakibatkan timbulnya gaya reaksi (Ry) pada kedua ujung tumpuan, yaitu pada tumpuan kepala tetap dan tail stock, karena minitube memiliki ketebalan yang kecil sehingga tidak mampu menahan gaya reaksi sehingga mengakibatkan pembesaran ukuran diameter minitube pada bagian ujung yang bertumpuan pada tailstock. Ilustrasi proses diatas digambarkan pada gambar 14.

Gambar 8 A menunjukkan ketidakhomogenan ukuran ketebalan minitube. Ketidakhomogenan ukuran ketebalan mintube disebabkan oleh proses boring dan face turning dilakukan pada mesin yang berbeda, terjadi pemindahan posisi material pada mesin yang mengakibatkan kesentrisan sumbu poros pada mesin dan kesentrisan posisi material terhadap sumbu poros mesin berubah, sehingga pada saat mesin beroperasi timbul simpangan $(\Delta \mathrm{x})$ pada material, hal ini menyebabkan terjadinya perbedaan ukuran ketebalan pada minitube. Besarnya simpangan yang terbesar adalah 0,41 mm yang terletak pada ujung minitube dengan jarak $25 \mathrm{~mm}$ dari kepala tetap mesin bubut. Ilustrasi simpangan ditampilkan pada gambar 9 .

Perbedaan ukuran ketebalan minitube menyebabkan bagian tertentu memiliki ketebalan yang lebih kecil dibandingkan bagian lainya. Bagian yang memiliki ketebalan yang paling kecil 
berpotensi mengalami keretakan seperti yang ditunjukan pada gambar 8 B. Keretakan terjadi karena adanya getaran pada mesin saat proses face turning. Hal ini mengakibatkan kegagalan pada saat proses pembuatan mintube, oleh sebab itu penggunaan tailstock dan pemindahan posisi material pada mesin bubut harus hindari untuk menghidari kegagalan pada saat proses pembuatan minitube.

Proses mechanical polishing dengan menggunakan kain bludru pada material AISI 316 L dan CP-Titanium grade 2 dilakukan untuk menghilangkan goresan (kerf) hasil proses face turning, sehingga dihasilkan permukaan minitube yang halus (smooth). Goresan (kerf) hasil proses face turning dapat dilihat pada gambar 13. Gambar 13 diambil dari penelitian yang dilakukan oleh Suryawan (2016). Harga kekasaran permukaan (Ra) hasil proses mechanical polishing untuk material AISI 3161 dan CP Ti 2 masing masingnya adalah 0,55 $\mu \mathrm{m}$ dan $0,45 \mu \mathrm{m}$. Perbedaan harga kekasaran permukaan antara AISI $316 \mathrm{~L}$ dan Cp-Titanium grade 2 disebabkan oleh perbedaan machineability kedua material. Harga kekasaran permukaan (Ra) hasil proses mechanial polishing masuk kedalam standar kekasaran permukaan ( $\mathrm{Ra}$ ) maximum untuk stent jantung yaitu 0,6 $\mu \mathrm{m}$ (Gocke, dkk., 2008).

Keuntungan membuat minitube dengan menggunakan mesin bubut adalah ketersedian mesin bubut yang mudah ditemukan dan tidak memerlukan peralatan khusus seperti proses pembuatan minitube dengan menggunakan metode multipass cold drawing (Fang, dkk, 2013), extrusion, single screw extruder, powder metallurgy, electroforming (Morajev \& Mantovani, 2011), selain hal diatas, keuntungan pembuatan minitube dengan menggunakan mesin bubut tidak merubah struktur mikro material sehingga tidak merubah sifat mekanik material. Proses pembuatan minitube dengan menggunakan metode extrusion dan proses cold drawing mengakibatkan perubahan strukturmikro material (Ge, dkk., 2012). Pembahasan diatas menunjukkan bahwa pembuatan minitube dapat dilakukan dengan menggunakan mesin bubut, dan proses mechanical polishing dapat digunakan untuk mengoptimalkan kekasaran permukaan minitube sebagai bahan baku stent jantung.

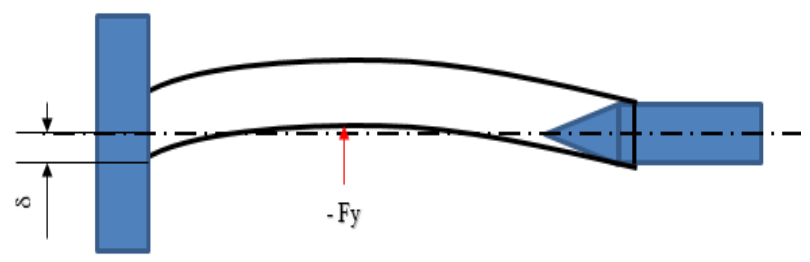

Gambar 14. Ilustrasi defleksi pada minitube.

\section{KESIMPULAN}

Proses pembuatan minitube untuk bahan baku ring jantung dapat dilakukan dengan menggunakan mesin bubut konvensional. Urutan proses pembuatan minitube yaitu boring dan face turning, konsistensi dalam penggunaan mesin menjadi faktor utama keberhasilan dalam membuat minitube dengan menggunakan mesin bubut konvensional. Ukuran minitube yang dihasilkan adalah $3 \mathrm{~mm}$ diameter dalam, 3,5 $\mathrm{mm}( \pm 0,1)$ diameter luar dan $30 \mathrm{~mm}$ panjang minitube. Proses mechanical polishing dapat digunakan sebagai surface finishing untuk menghaluskan permukaan minitube sebelum dilakukan proses fabrikasi pembuatan ring jantung, harga kekasaran permukaan $(\mathrm{Ra})$ hasil proses mechanical polishing masuk kedalam standar harga kekasaran permukaan $(\mathrm{Ra})$ ring jantung. 


\section{DAFTAR PUSTAKA}

Catalano, G., Demir, A. G., Furlan, V., \& Previtali, B. (2017). Use of Sheet Material for Rapid Prototyping of Cardiovascular rings. Procedia Engineering : 17 th International Confrence on Sheet metal SHEMET 17, 183, 194-199.

Demir, A. G., Previtali, B., \& Biffi, C. A. (2013). Fiber Laser Cutting and Chemical Etching of AZ31 for Manfacturing Biodegradable Rings. Advance in Material Science and Engineering, 2013, 1-10.

Dong, J., Liao, L., Tan, Z., Fan, Z., Li, S., \& Lu, Z. (2013). A boresorbable Cardiovascular Ring Prepared From L-Lactide, Trimethylene Carbonate and Glycolide Terpolymers. Polymer Engineering and Science, 1418-1426. doi:10.1002/pen.23662

Fang, G., Ai, W. J., Leeflang, S., Duszczyk, J., \& Zhou, J. (2013). Multipass Cold Drawing of Magnesium Alloy Minitubes for Biodegradable Vascular Rings. Materials Science and Engineering, 33, 3481-3488.

Ge, Q., Vedani, M., \& Vimercati, G. (2012). Extrusion of Magnesium Tubes for Biodegradable Ring Precusors. Materials and Manufacturing Processes, 27(2), 140-146.

Gocke, C., Grabow, N., Schultze, C., Sternberg, K., Schmidt, W., \& Schmitz, K. P. (Nov 2008). Coating Homogenity in the Manufacture of Drug Eluting Stens. 4th European Confrence of the International Federation for Medical and Biological Engineering (hal. 2241-2246). Belgium: Springer Verlag.

Hassel, T., Bach, F. W., \& Golovko, A. N. (2007). Production and Properties of Small Tubes Made from $\mathrm{MgCa} 0,8$ for application as Ring in Biomedical Science. Proceedings of 7 th Internatonal Confrence on Magnesium Alloys and Their Applications . Dresden.

Hermawan, H., \& Mantovani, D. (2013). Process of prototyping Coronary Ring from Biodegradable Fe-Mn Alloys. Acta Biomateriala, 9(10), 8585-8592.

Huang, B., Gale, D. C., \& Gueriguian, V. J. (2009, June 11). United State Paten No. US 20090146348A1.

Lampman, S. (1994). Wrought Titanium and Titanium Alloy. Dalam ASM Metal Handbook Vol 2 : Non Ferous Alloy. America: ASM International.

Li, J., Yang, Y., ren, Y., Dong, J., \& Yang, K. (2017). Effect of Cold Deformation on Corrosion Fatigue Behavior of Nickel-Free High Nitorgen Austenitic Stainless Steel for Coronary Ring Application. Material Science and Technology, 34(4), 660-665.

Mazinani, A. (2014). Surface Modification Treatment of cardiovascular Ring. Milan: Department of Chemistry, Materials and Chemical Engineering, Politecnico Di Milano.

Morajev, M., \& Mantovani, D. (2011). Biodegradable Metals for Cardiovascular Ring Application : Interests and New Opportunities. International Journal of Molecular Science, 12, 4250-4270.

Nordin, J. A., Nasution, A. K., \& Hermawan, H. (2013). Can the Current ring Manufacturing Process be Used for Making Metallic Biadegradable Rings? Advanced Materials Research, 746, 416-421.

Pilliar, R. M. (2009). Austenitic Stainless Steel 316 L. Dalam Metallic Biomaterials. Springer Science .

Ratner, B. R. (2004). Biomaterial Science " An Introduction to Materials in Medicine". Amerika: Elesevier Academic Press.

Raval, A., Choubey, A., Engineer, C., \& Kothwala, D. (2005). Surface Conditioning of 316LVM Slotted Tube Cardiovascular Rings. Journal of Biomaterial Applications, 19(3), 197-213. 
Saraf, A. R., \& Yadav, A. P. (2018). Fundamental of Bare Metal Ring. Dalam Functionalized Cardiovascular Ring (hal. 27-28). Amerika: Woodhead Publishing.

Sojitra, P. (2010). Electropolishing of 316 L Stainless Steel Cardiovascular Ring : An Investigation of Material Removal, Surface Roughness and Corrosion Behaviour. Trends Biometer, 23(3), 115-121.

Stoeckel, D., Bonsignore, C., \& Duda, S. (2002). A Survey of Ring Design. Minim. Invansive Ther. Allied Technol., 11(4), 137-147.

Suryawan, D. (2017). Desain, Pemodelan, dan Pembuatan Prototype Ring Jantung Menggunakan Electrical Discharge Machining (EDM). Yogyakarta: Fakultas Teknik UGM.

Tontowi, A., Adani, R. A., Setyaningsih, I. S., \& Taufik, N. (2014). Analysis of User Acceptibility Factors for Optimum Design of Coronary Ring. International Confrence on Biomedical Engineering, Technology, and Applications, 1, hal. 1-6. Yogyakarta. 